\title{
Two cytotoxic triterpenes from cultures of a Kenyan Laetiporus sp. (Basidiomycota)
}

Clara Chepkirui ${ }^{\mathrm{a}, \mathrm{b}}$, Josphat Clement Matasyoh ${ }^{\mathrm{c}}$, Cony Decock ${ }^{\mathrm{d}}$ and Marc Stadler ${ }^{\mathrm{a}, \mathrm{b}}$ *

${ }^{a}$ Helmholtz Centre for Infection Research GmbH (HZI), Department Microbial Drugs,

Inhoffenstraße 7, 38124 Braunschweig, Germany.Email:Clara.Chepkirui@helmholtz-hzi.de.

${ }^{b}$ German Centre for Infection Reseach Association (DZIF), Partner site Hannover-

Braunschweig, Inhoffenstraße 7, 38124 Braunschweig, Germany.

${ }^{c}$ Egerton University, Department of Chemistry, P.O BOX 536, 20115, Njoro, Kenya. Email:

josphat2001@yahoo.com

${ }^{d}$ Mycothéque de l' Universite catholique de Louvain (BCCM/MUCL), Place Croix du Sud 3,

B-1348Louvain-la-Neuve,Belgium.Email:cony.decock@uclouvain.be

* Corresponding author. Tel.: +49 531 6181-4240; fax: 49531 6181-9499; e-mail:

marc.stadler@helmholtz-hzi.de 


\begin{abstract}
HPLC profiling of the mycelial culture of a poroid basidomycete collected in Mount Elgon, Kenya, which probably represents a new species of the genus Laetiporus, led to isolation of two previously undescribed lanostane type triterpenes.We propose the trivial names laetiporins A (1) and B (2). In addition, five known ones: dehydrosulphurenic acid (3), sulphurenic acid (4), eburicoic acid (5), 15 $\alpha$-hydroxytrametenolic acid (6) and trametenolic acid (7) were also isolated. The laetiporins (1-2) exhibited significant cytotoxic effects against various human cancer cells. The known compounds (3-5) and (7) also showed moderate cytotoxic activity, but none of the compounds showed any significant antimicrobial activity.
\end{abstract}

Keywords: Cytotoxicity; Fungi: Polyporales; Terpenoids 


\subsection{Introduction}

Exploitation of natural resources in particular fungi in search of new bioactive compounds has been an emerging field of study. Basidiomycetes seem greatly promising as sources for new, interesting classes of compounds of different biogenetic origins with various biological activities (De Silva et al., 2013, Richter et al., 2015). Even though the tropics are the home of most of the basidiomycetes species, its riches remain largely untapped. Previously we reported the isolation of several new bioactive compounds from the Kenyan basidiomycetes Favolaschia calocera and Laxitextum incrustatum (Chepkirui et al., 2016, Mudalungu et al., 2015).

In our present study, several strains of a Laetiporus species (Polyporaceae) originating from Kenya were investigated. Laetiporus is one of the few polypore genera that produce conspicuous basidiomes that are edible when young, such as L. sulphureus, the common wellknown "chicken of the woods". The genus has a world-wide distribution. Laetiporus spp. also have been recognized as important forest pathogens, causing a cubical brown rot in living and dead wood of both conifers and angiosperms (Banik et al., 2010).

\subsection{Experimental section}

2.1.1 General experimental procedure. Optical rotations were determined with a PerkinElmer 241 spectrometer; UV spectra were recorded with a Shimadzu UV-vis spectrophotometer UV-2450. NMR spectra were recorded with Bruker Ascend 700 spectrometer with $5 \mathrm{~mm}$ TXI cryoprobe $\left({ }^{1} \mathrm{H} 700 \mathrm{MHz},{ }^{13} \mathrm{C} 175 \mathrm{MHz}\right)$ and Bruker AV II-600 ( $\left.{ }^{1} \mathrm{H} 600 \mathrm{MHz},{ }^{13} \mathrm{C} 150 \mathrm{MHz}\right)$ spectrometers. HR-ESI-MS mass spectra were recorded with Agilent 1200 series HPLC-UV system (column2.1 x 50 mm, $1.7 \mu \mathrm{m}$, C18 Acquity UPLC BEH (waters), solvent $\mathrm{A}: \mathrm{H}_{2} \mathrm{O}+0.1 \%$ formic acid; solvent $\mathrm{B}$ : $\mathrm{AcCN}+0.1 \%$ formic acid, gradient: $5 \% \mathrm{~B}$ for 0.5 minutes increasing to $100 \% \mathrm{~B}$ in 19.5 minutes and then maintaining $100 \% \mathrm{~B}$ for 5 minutes, flow rate $0.6 \mathrm{ml} / \mathrm{min}^{-1}$, uv/vis detection 200-600 nm combined with ESI-TOF-MS (Maxis, Bruker) [scan range $100-2500 \mathrm{~m} / \mathrm{z}$, capillary voltage $4500 \mathrm{~V}$, dry temperature $\left.200{ }^{\circ} \mathrm{C}\right]$.

2.1.2 Fungal material: The fungal strain Laetiporus sp. was collected from Kakamega equatorial rainforest, located in the western part of Kenya $\left(0^{\circ} 17^{\prime} 3.19^{\prime \prime} \mathrm{N} 34^{\circ} 45^{\prime} 8.24^{\prime \prime}\right.$ E) on a dead fallen trunk of Bridelia micrantha (Phyllanthaceae) by C. Decock, Feb. 17, 2015 (collection and isolation number KE-15-22). The dried herbarium specimen 
and culture are deposited at MUCL, Louvain-la-Neuve, Belgium as MUCL 55532. The fungus was assigned to the genus Laetiporus by morphologcal studies and sequencing of the rDNA (5.8S gene region, the internal transcribed spacer ITS1 and ITS2). This fungus probably represents a new taxon and is presently being included in a large study on the phylogeny and taxonomy of the genus Laetiporus in Africa. Genomic DNA Miniprep kit (Bio Basic Canada Inc., Markham, Ontario, Canada). A Precellys 24 homogenizer (Bertin Technologies, France) was used for cell disruption at a speed of $6000 \mathrm{rpm}$ for $2 \times 40 \mathrm{~s}$. The gene regions were amplified with primers ITS 1f and NL4.

2.1.3 Small scale fermentation: Laetiporus sp. strain MUCL 55532 was cultivated in three different liquid media YMG, Q6 $1 \frac{1}{2}$ and ZMำ media (for details on the composition of these media see Supplementary Information). These three media were selected because previous studies had revealed that they were optimal for attaining complementary secondary metabolites profiles in filamentous fungi (Bitzer et al., 2008). A well grown culture grown on an YMG agar plate was cut into small pieces using a cork borer $(7 \mathrm{~mm})$ and five pieces inoculated in a batch of ten $500 \mathrm{ml}$ Erlenmeyer flask containing $200 \mathrm{~mL}$ of the three media. The cultures were incubated at $23{ }^{\circ} \mathrm{C}$ on a rotary shaker (140 rpm). The growth of the fungus was monitored by constantly checking the amount of free glucose (using Bayer Diastix Harnzuckerstreifen). The fermentation was terminated two days after glucose depletion (Bitzer et al., 2008).

2.1.4 Extraction of the small scale fermentation crude extracts: The supernatant and the mycelia from the small scale fermentation were separated by filtration. The supernatant was extracted with equal amount of ethyl acetate and filtered through anhydrous sodium sulphate. The resulting ethyl acetate extract was evaporated to dryness by means of rotary evaporator. The mycelia were extracted with $200 \mathrm{~mL}$ of acetone in ultrasonic bath for 30 minutes, filtered and the filtrate evaporated. The remaining water phase was suspended in equal amount of distilled water and subjected to same procedure as the supernatant. The mycelia and supernatant crude extracts from the three media HRMS were measured. Analysis of the MS spectra by comparing the masses of the detected peaks and their molecular formula obtained from HRMS with those in the data base (Dictionary of natural products) led to the identification of the new compounds on the YMG mycelia crude extract (Dictionary of Natural Products on DVD, 2016). 
2.1.5 Large scale fermentation: A well-grown seven days old YMG agar plate of the mycelial culture was cut into small pieces using a $7 \mathrm{~mm}$ cork borer and five pieces inoculated in $1000 \mathrm{~mL}$ Erlenmeyer flask containing $500 \mathrm{~mL}$ (10 flasks) of YMG medium. The culture was incubated at $23{ }^{\circ} \mathrm{C}$ on a rotary shaker (140 rpm) for 36 days. Fermentation was aborted 2 days after the depletion of free glucose.

2.1.6 Extraction of the large scale fermentation crude extracts: The mycelia and supernatant from the large scale fermentation were separated via vacuum filtration. The mycelia were extracted with 4 x $500 \mathrm{~mL}$ of acetone in ultrasonic bath for $30 \mathrm{~min}$. The extracts were combined and the solvent evaporated by means of a rotary evaporator. The remaining water phase was subjected to the same procedure as mycelium in small scale extraction three times yielding white solid (1.2 g). The supernatant on the other hand was mixed with $100 \mathrm{~g}$ adsorbent resin (Amberlite XAD ${ }^{\mathrm{TM}_{-}} 16 \mathrm{~N}$ ) and incubated overnight on a shaker. The Amberlite resin was then filtered and eluted with 4 x 500 $\mathrm{mL}$ acetone. The resulting acetone extract was evaporated and the remaining water phase subjected to the same procedure as the acetone water phase of the mycelia to afford $250 \mathrm{mg}$ dark brown solid.

2.1.7 Isolation and purification: The mycelia crude extract was fractionated using preparative reverse phase liquid chromatography (PLC 2020, Gilson, Miiddleton, USA). VP Nucleodur 100-5 C 18 ec column (250 x 40, $7 \mu \mathrm{m}$ : Macherey-Nagel) used as stationary phase. Deionized water (Milli-Q, Millipore, Schwalbach, Germany) (solvent A) and acetonitrile (solvent B) were used as the mobile phase. Elution gradient used was 5- 100\% solvent B in 60 minutes and thereafter isocratic condition at $100 \%$ solvent B for 5 minutes. UV detection was carried out at 210, 254 and 350 $\mathrm{nm}$. Ten fractions were collected according to the observed peaks (F-1 - F-10) for mycelia extract. For details on the purification of fractions see SI.

2.1.8 Antimicrobial assay: The antifungal and antibacterial activities Minimum Inhibition Concentrations (MIC) were determined in serial dilution assay as described previously (Halecker et al., 2014, Okanya et al., 2011) against Candida tenuis MUCL29982, Mucor plumbeus MUCL49355, Escherichia coli DSM498 and Bacillus subtilis DSM10. The assays were carried out in 96-well microtiter plates in YMG media for filamentous fungi and yeast and EBS for bacteria. For the small scale fermentation extracts and pure compounds the starting concentration was $300 \mu \mathrm{g} / \mathrm{mL}$.

2.19 Cytotoxicity assays: In vitro cytotoxicity (IC50) of compound 1-7 was determined against a panel of mammalian cell lines including mouse fibroblast L929, HeLa (KB-3- 
1), epidermoid carcinoma cells A431, breast cancer cells MCF-7, prostate cancer cells PC-3 and adenocarcinomic human alveolar basal epithelial cells A549. The cell lines L929, KB 3.1 and A549 were cultured in DMEM (Gibco), PC-3 in F12-K (Gibco), MCF7 and A431 in RPMI (Gibco) media, all supplemented with 10\% of fetal bovine serum (Gibco) under $10 \% \mathrm{CO}_{2}$ at $37{ }^{\circ} \mathrm{C}$. The cytotoxicity assay was performed according to the MTT (3-(4,5-dimethylthiazol-2-yl)-2,5 diphenyltetrazolium bromide) method in 96-well microplates (Mosmann, 1983). Briefly $60 \mu \mathrm{L}$ aliquots of serial dilutions from an initial stock of $1 \mathrm{mg} / \mathrm{mL}$ in $\mathrm{MeOH}$ of the test compounds were added to $120 \mu \mathrm{L}$ aliquots of a cell suspension $(50000 \mathrm{~mL}$ ) in 96-well microplates. After 5 days incubation, a MTT assay was performed, and the absorbance measured at $590 \mathrm{~nm}$ using an ELISA plate reader (Victor). The concentration at which the growth of cells was inhibited to $50 \%$ of the control $\left(\mathrm{IC}_{50}\right)$ was obtained from the dose response curves. Negative control was methanol.

\section{Results and Discussion}

Crude extract fractionation and subsequent purification by reverse phase HPLC led to the isolation of two previously undescribed metabolites, for which we propose the trivial names, Laetiporin A (1) and B (2), together with the five known compounds: dehydrosulphurenic acid (3) (Wu et al., 2005), sulphurenic acid (4) (Frid et al., 1964), eburicoic acid (5) (Kariyone and Kurono, 1940), 15 $\alpha$-hydroxytrametenolic acid (6) (Yang et al., 1996) and trametenolic acid (7) (Yoshikawa et al., 2000) (Fig. 1). The known compounds were identified by comparing their NMR and HR-MS data with those reported in the literature.

Compound 1 was isolated as a white solid with the molecular formula $\mathrm{C}_{31} \mathrm{H}_{48} \mathrm{O}_{3}$ and 8 levels of unsaturation established from HRMS. Peaks at m/z 469.3679 for $[\mathrm{M}+\mathrm{H}]^{+}$and $\mathrm{m} / \mathrm{z}$ 451.35720 for $\left[\mathrm{M}+\mathrm{H}-\mathrm{H}_{2} \mathrm{O}\right]^{+}$were further observed in the HRMS. Moreover calculation for monoisotopic peak for compound $\mathbf{1}\left(\mathrm{C}_{31} \mathrm{H}_{48} \mathrm{O}_{3}\right)$ will be $468.7110 .{ }^{13} \mathrm{C}$ NMR spectroscopic data revealed the presence of 31 carbon signals, including seven methyl groups, nine methylenes, and five methines (Table 1). The ${ }^{1} \mathrm{H}$ NMR spectrum exhibited five singlet methyl groups at $\delta$ $0.70(\mathrm{H}-30), 0.75(\mathrm{H}-18), 0.92(\mathrm{H}-29), 0.96(\mathrm{H}-19)$ and $1.81(\mathrm{H}-31)$, one doublet at $\delta 0.97(\mathrm{H}-$ 26/27), one hydroxymethine at $\delta 3.01$, two olefinic singlets at $\delta 4.64$ and 4.72 and a broad doublet at $\delta 4.34$ for a hydroxy group. 
The HMBC correlations of $\mathrm{H}-19$ to C-1/ C-5/C-9/C-10, H-29 and H-30 to C-3/C-4/ C-5, H-18 to $\mathrm{C} 12 / \mathrm{C}-13 / \mathrm{C}-14 / \mathrm{C}-17$ and $\mathrm{H}-14$ to $\mathrm{C}-12 / \mathrm{C}-18$ suggested a lanostane skeleton. Further, HMBC correlations between H-31 to C-15/C-16/C-17, H-15 to C-17/C-16, H-19 and H-12 to C-9 and H-6 and H-7 to C-8 confirmed the positions of the two double bounds (Fig. 1). The $\mathrm{OH}$ proton $(\delta 4.34)$ showed HMBC correlations to $\mathrm{C}-2 / \mathrm{C}-3$. The side chain connection was established from the HMBC correlations of H-20 to C-17. Correlations between methylene protons H-22 and H-20 to C-21 were also observed. H-23 showed HMBC correlation to C20/C-22/C-24/C-25/C-28. The position of exomethylene group at C-24 ( $\delta 154.8)$ was established from HMBC correlation of H-28 to C-23/C-24/C25. This was further supported by $\mathrm{H}-26 / \mathrm{H}-27$ correlation to $\mathrm{C}-24$ and long range COSY correlation of $\mathrm{H}-28(\delta 4.64)$ to $\mathrm{H}-23$ ( $\delta$ 1.93). In the COSY spectrum, correlations were observed between $\mathrm{H}-1 / \mathrm{H}-2, \mathrm{H}-3 / \mathrm{H}-2, \mathrm{H}-6 / \mathrm{H}-$ 5, H-7, H-11/H-12, H-14/H-15, H-22/H-20, H-23, H-25/H-26 and H-27.

Important ROESY correlations, which gave an indication of the orientation in space of some groups at various stereocenters were observed. These correlations included: $\mathrm{H}-18$ to $\mathrm{H}-12$ ( $\delta$ 1.67)/H-19/ H-20 and H-30 to H-6 ( $\delta 1.40) / \mathrm{H}-19$. The ROESY correlations of H-3 to H-5/H29 and the coupling constant of $J=4.58,4.73$ and $10.38 \mathrm{~Hz}$ ) for this proton suggesting $\alpha$ orientation of H-3. Further, correlations between $\mathrm{H}-5$ to $\mathrm{H}_{\alpha}-7$ and $\mathrm{H}-14 / \mathrm{H}_{\alpha}-7 / \mathrm{H}_{\alpha}-15$ were also observed. For detailed ROESY correlations see SI.

The absolute configuration of 1 was determined using Mosher's method (Hoye et al., 2007). The $(S)$ and $(R)$-MTPA esters were obtained by treatment of 1 with $(R)-(-)$ and $(S)-(+)$ MTPA chloride respectively. The $\Delta \partial \mathrm{SR}=\partial(S$-MTPA ester $)-\partial(R$-MTPA ester $)$ for protons neighboring C-3 led to the assignment of S- configuration at C-3 (Table 1-SI). Therefore using C-3 as a reference the other stereocenters were assigned as $5 R, 10 S, 13 R, 14 R$ and $20 S$. Compound 2 was obtained as a white solid. From the HRMS its molecular formula was deduced as $\mathrm{C}_{34} \mathrm{H}_{52} \mathrm{O}_{7}$ with nine degrees of unsaturation. Peaks at $\mathrm{m} / \mathrm{z} 573.3786$ for $[\mathrm{M}+\mathrm{H}]^{+}$ and $\mathrm{m} / \mathrm{z} 555.3880$ for $\left[\mathrm{M}+\mathrm{H}-\mathrm{H}_{2} \mathrm{O}\right]^{+}$were observed in the HRMS. Furthermore, calculation for monoisotopic peak for compound $2\left(\mathrm{C}_{34} \mathrm{H}_{52} \mathrm{O}_{7}\right)$ will be 572.3713 . Analysis of the ${ }^{1} \mathrm{H}$ NMR and ${ }^{13} \mathrm{C}$ NMR of $\mathbf{2}$ suggested a closely related structure to that of $\mathbf{1}$ with the difference being observed in ring $\mathrm{C}$ and $\mathrm{D}$ (Fig 1). The ${ }^{1} \mathrm{H}$ NMR spectrum indicated five singlet methyl groups at $\delta 0.69(\mathrm{H}-30), 0.76(\mathrm{H}-18), 0.89(\mathrm{H}-29), 0.91(\mathrm{H}-19)$ and $0.93(\mathrm{H}-31)$, one doublet at $\delta 0.93$ (H-26/27), methylene singlet at $\delta 3.28$, two oxygenated methines at $\delta 2.99(\mathrm{H}-3)$ and $4.92(\mathrm{H}-$ 15), two olefinic singlets at $\delta 4.63$ and 4.72 and a broad doublet at $\delta 4.31$ for a hydroxy group. 
The HMBC correlations of H-19 to C-1/ C-5/C-9/C-10, H-29 and H-30 to C-3/C-4/ C-5, H-18 to $\mathrm{C} 12 / \mathrm{C}-13 / \mathrm{C}-14 / \mathrm{C}-17$ and $\mathrm{H}-31$ to $\mathrm{C}-8 / \mathrm{C}-13 / \mathrm{C}-14 / \mathrm{C}-15$ suggested a lanostane skeleton like in $\mathbf{1}$. However, for compound $\mathbf{2}$ the double bond at $\mathrm{C}-16 / \mathrm{C} 17$ in $\mathbf{1}$ was missing and position of C-31 was also shifted to C- 14 ( $\delta 50.3)$. This was supported by the HMBC correlation of $\mathrm{H}-31$ ( $\delta 0.93)$ to C-8/C-13/C-14/C-15. Signals at $\delta 34.7$ for a methylene (C-16) and $\delta 75.5$ for oxygenated methine (C-15) were also observed in the ${ }^{13} \mathrm{C}$ NMR spectrum. The side chain connection was established from the HMBC correlations of $\mathrm{H}-17$ to $\mathrm{C}-20 / \mathrm{C}-21$ and the COSY correlation between H-17 and H-20. 1D and 2D NMR data suggested a similar side chain as in $\mathbf{1 .}$

The molecular formula $\mathrm{C}_{34} \mathrm{H}_{52} \mathrm{O}_{7}$ indicated that compound 2 should have 34 carbon atoms but only 31 carbon atoms in the ${ }^{13} \mathrm{C}$ NMR spectrum of compound 2 in DMSO were observed. However, the analysis of the 2D NMR data, in particular of the HMBC spectrum, suggested additional peaks at $\delta 42\left(-\mathrm{CH}_{2}\right), \delta 167.0(\mathrm{C}=\mathrm{O})$ and $\delta 167.9(\mathrm{C}=\mathrm{O})$. Hence, the ${ }^{13} \mathrm{C} \mathrm{NMR}$ spectrum was re-measured in methanol- $\mathrm{d}_{4}$ and the missing carbons could be observed (for the spectrum see Supplementary information). The additional methylene protons were correlated to $\mathrm{C}-32$ and $\mathrm{C}-34$ in the $\mathrm{HMBC}$ spectrum, implying the presence of a malonyl group, which is attached to $\mathrm{C}-15$ ( $\delta 75.5)$ as deduced from the HMBC correlation of $\mathrm{H}-15$ to $\mathrm{C}-32$. This assignment was further supported by the downfield shift of H-15 ( $\delta 4.92)$. A closely related polyporenic acid derivative has been reported before from the basidiomycete Piptoporus betulinus with the difference being on the side chain and the position of the malonyl group (Tsunashi et al., 2003).

Similar ROESY correlations as for $\mathbf{1}$ were observed, but with additional correlations between H-15/H-7 ( $\delta$ 1.80)/H-18 and H-31/H-7 (2.01)/H-17 (Fig. 2). Conversion of 2 to $(S)$ and $(R)$ MTPA esters gave similar results as for 1 . Therefore, the stereocentres were assigned as $3 \mathrm{~S}$, $5 R, 10 S, 13 R, 14 R, 15 S, 17 R$ and $20 S$.

The compounds 1-7 were subjected to antimicrobial assays against Candida tenuis MUCL29982, Mucor plumbeus MUCL49355, Escherichia coli DSM498 and Bacillus subtilis DSM10, but no activity was observed against these test organisms at concentrations $\leq 300$ $\mu \mathrm{g} / \mathrm{mL}$. Compound 1-5 and 7 were further subjected to cytotoxicity tests against various mammalian cell lines. Compound $\mathbf{1}$ and $\mathbf{2}$ exhibited significant cytotoxicity against various human cancer cell lines (Table 1). The highest activity of 1 was recorded against KB3.1, MCF-7, PC-3 and A549 ( $\left.\mathrm{IC}_{50} 4.5-7.2 \mu \mathrm{g} / \mathrm{mL}\right)$. The activities of compound 2 against the tested 
cell line were in the rage of $46-67 \mu \mathrm{g} / \mathrm{mL}$. Compound 3 showed moderate cytotoxicity against the six tested cell lines with $\mathrm{IC}_{50}$ in the range $9.8-27 \mu \mathrm{g} / \mathrm{mL}$. Stronger activities of 4 in the range of 3.5-8.2 $\mu \mathrm{g} / \mathrm{mL}$ were observed against the same cell lines. Compound 4 have been reported before to be potent against MDA-MB-231 cells and MCF-7 cells (Yeh et al., 2009). 5 exhibited activity against KB3.1 when tested by us, but no significant activity was observed against L929 at concentration $\leq 37 \mu \mathrm{g} / \mathrm{ml}$. Compound 5 has been reported previously to have anticancer activities (Jiang-Bo et al., 2015, Su et al., 2011). Compound 7 did not exhibit any cytotoxicity against L929 and KB3.1 at concentration $\leq 37 \mu \mathrm{g} / \mathrm{ml}$ and therefore was not tested against the other cell lines. Due to limited material compound 6 was not tested.

\subsection{Conclusion.}

Two previously undescribed triterpenes together with five known ones were isolated from the mycelial culture of a Kenyan basidiomycete belonging to the genus Laetiporus. The isolated compounds 1-4 showed moderate cytotoxicity activity against various cancer cell lines.

Compound 5, which was only active against L929 cells in our initial tests, was not tested any further. Triterpene or steroids are an important class of compounds that are widely distributed in nature. Although triterpenoids were considered to be biologically inactive for a long time, accumulating evidence on their broad spectrum pharmacological activities coupled with a low toxicity profile has sparked renewed interest with regard to their application especially in cancer treatment (Anupam et al., 2011). Several triterpenes like laetiposides A-D and sulphurenic acid have been isolated from the genus Laetiporus (Wu et al., 2005, Yoshikawa et al., 1999, 2000).

\subsection{Chemical data}

Laetiporin A (1): White solid. [ $\alpha] \mathrm{D} 20=-11.1,(\mathrm{c} 1.00, \mathrm{MeOH}) . \mathrm{UV}(\mathrm{MeOH}, \mathrm{c}=0.05) \lambda_{\max }$ (log ع) 244 (3.890). HRMs m/z $469.3679[\mathrm{M}+\mathrm{H}]^{+}$, calcd for $\mathrm{C}_{31} \mathrm{H}_{48} \mathrm{O}_{3} 468.711$.

Laetiporin B (2): White solid. [ $\alpha$ ]D20 $=+56.1$, (c 1.00, $\mathrm{MeOH}) . \quad \mathrm{UV}(\mathrm{MeOH}, \mathrm{c}=0.05)$ $\lambda_{\max }(\log \varepsilon) 201$ (3.780). HRMs m/z 573.3786 [M+H ] , calcd for $\mathrm{C}_{34} \mathrm{H}_{52} \mathrm{O}_{7} 572.3713$.

\section{Acknowledgments}

We are grateful to Wera Collisi, Christel Kakoschke and Cäcilia Schwager for their technical support and to Dr. Soleiman E. Helaly for valuable scientific discussion. Financial 
support by the "ASAFEM" Project (Grant no. IC-070) under the ERAfrica Programme to J.C.M. and M.S. and a personal $\mathrm{PhD}$ stipend by the German Academic Exchange Service (DAAD) and the Kenya National Council for Science and Technology (NACOSTI) to C.C. is gratefully acknowledged (programme-ID: 57139945).

\section{Supplementary information}

For detailed description of some experimental procedures, copies of the HR-ESI-MS, UV, 1-D and 2-D NMR spectra of compounds 1 and 2 see SI.

\section{References}

1. Anupam, B., Shamima, A., Nikoleta, B., Marjorie, P., 2011. Triterpenoids as potential agents for the chemoprevention and therapy of reast cancer. Front. Biosci. 16, 980-996.

2. Banik, M.T., Lindner, D.L., Ota, Y., Hattori, T., 2010. Relationships among North American and Japanese Laetiporus isolates inferred from molecular phylogenetics and single-spore incompatibility reactions. Mycologia 102, 911-917.

3. Bitzer, J., Læssøe, T., Fournier, J., Kummer, V., Decock, C., Tichy, H.V., Piepenbring, M., Persoh, D., Stadler, M., 2008. Affinities of Phylacia and the daldinoid Xylariaceae, inferred from chemotypes of cultures and ribosomal DNA sequences. Mycol. Res. 112, 251-270.

4. Chepkirui, C. Richter, C. Matasyoh, J.C., Stadler, M., 2016. Monochlorinated calocerins A-D and 9-oxostrobilurin derivatives from the basidiomycete Favolaschia calocera. Phytochemistry.132, 95-101.

5. De Silva, D.D., Rapior, S., Sudarman, E., Stadler, M., Xu, J., Aisyah, S.A., Hyde, K.D., 2013. Bioactive metabolites from macrofungi: ethnopharmacology, biological activities and chemistry. Fungal Divers. 62, $1-40$.

6. Dictionary of Natural Products on DVD, 2016. Chapman \& Hall, Chemical Data Base; CRC: Boca Raton, FL.

7. Fried, J., Grabowich, P., Sabo, E.F., Cohen, A.I., 1964. The structure of sulphurenic acid: A new triterpenoid from Polyporus sulphureus.Tetrahedron. 20, 2297-2312.

8. Halecker, S., Surup, F., Kuhnert, E., Mohr, C., Brock, N., Dickschat, J., Junker, C., Schulz, B., Stadler, M., 2014. Hymenosetin, a 3-decalinoyltetramic acid antibiotic from cultures of the ash dieback pathogen, Hymenoscyphus pseudoalbidus. Phytochemistry 100, 86-91. 
9. Hoye, T.R., Jeffrey, C.S., Shao, F., 2007. Mosher ester analysis for the determination of absolute configuration of stereogenic (chiral) carbinol carbons. Nature Protocols. 2, 24512458.

10. Jiang-Bo, H., Jian, T., Xi-Song, M., Wei, B., Shen, Z., Zheng-Hui, L., Tao, F., Ji-Kai, L., 2015. Seven new drimane-type sesquiterpenoids from cultures of fungus Laetiporus sulphurous. Fitoterapia. 102, 1-6.

11. Kariyone, T., Kurono, G., 1940. A Constituent of Formes officinalis Fris. J. Pharm. soc. Japan. 60, 318.

12. Mudalungu, C.M., Richter, C., Wittstein, K., Abdalla, A.M., Matasyoh, J.C. Stadler, M., Süssmuth, R.D., 2015. Laxitextines A and B, cyathane xylosides from the tropical fungus Laxitextum incrustatum. J. Nat. Prod.79, 894-898.

13. Okanya, P.W., Mohr, K.I., Gerth, K., Jansen, R., Müller, R., 2011. Marinoquinolines A-F, Pyrroloquinolines from Ohtaekwangia kribbensis (Bacteroidetes). J. Nat. Prod. 74, 603-608.

14. Richter, R., Wittstein, K., Kirk, P.M., Stadler, M., 2015. An assessment of the taxonomy and chemotaxonomy of Ganoderma. Fungal Divers. 71, 1-15.

15. Su, Y., Liu, C., Chu, Y., Raghu, R., Kuo,Y., Sheen, L., 2011. Eburicoic acid, an active triterpenoid from the fruiting bodies of basswood cultivated Antrodia cinnamomea, induces ER stress-mediated autophagy in human hepatoma Cells. 2(4), 312-322.

16. Tsunashi, K, Masashi, A, Hisao, S., Mitsuru, H., 2003. Anti-inflammatory lanostane-Type triterpene acids from Piptoporus betulinus. 66, 1104-1106.

17. Wu, X, Yang, J.S., Dong, Y.S., 2005. Chemical constituents of Fomes officinalis. Chin. Tradit. Herb. Drugs. 36, 811-814.

18. Yang, S.W., Shen, Y.C., Chen, C.H., 1996. Steroids and triterpenoids of Antrodia cinnamomea - a fungus parasitic on Cinnamomum micranthum. Phytochemistry. 41, 1389-1392.

19. Yeh, C., Rao, Y.,Yao , K., Yeh, C., Li, C., Chuang, S., Luong, J.H.T., Lai, G., Tzeng, Y., 2009. Cytotoxic triterpenes from Antrodia camphorata and their mode of action in HT-29 human colon cancer cells. Cancer Lett., 285 73-79.

20. Yoshikawa, K., Matsumoto, K, Mine, C., Bando, S., Arihara, S., 2000. Two new steroidal derivatives from the fruit body of Chlorophyllum molybdites. Chem. Pharm. Bull. 48, 1418-1421.

21. Yoshikawa, K., Matsumoto, K., Arihara, S.J., 1999. New lanostanoid glycosides from the fruit body of Laetiporus versisporus. J. Nat. Prod. 62, 540-542. 
Table 1. NMR data for compounds 1 and 2 in DMSO-D $6\left({ }^{1} \mathrm{H} 500 \mathrm{MHz},{ }^{13} \mathrm{C} 150 \mathrm{MHz}\right)$

\begin{tabular}{|c|c|c|c|c|c|c|}
\hline No. & ${ }^{13} \mathrm{C}$ & DEPT & ${ }^{1} \mathrm{H} / \mathrm{HSQC}$ & ${ }^{13} \mathrm{C}$ & DEPT & ${ }^{1} \mathrm{H} / \mathrm{HSQC}$ \\
\hline 1. & 35.9 & $\mathrm{CH}_{2}$ & $\begin{array}{l}1.16(\mathrm{~m}) \\
1.72(\mathrm{~m})\end{array}$ & 35.1 & $\mathrm{CH}_{2}$ & $\begin{array}{l}1.11(\mathrm{~m}) \\
1.62(\mathrm{~m})\end{array}$ \\
\hline 2. & 27.7 & $\mathrm{CH}_{2}$ & $\begin{array}{l}1.52(\mathrm{~m}) \\
1.18(\mathrm{~m})\end{array}$ & 27.5 & $\mathrm{CH}_{2}$ & $1.48(\mathrm{~m})$ \\
\hline 3. & 76.5 & $\mathrm{CH}$ & $\begin{array}{l}3.01 \text { (br ddd), } J=4.58,4.73 \\
10.38 \mathrm{~Hz}\end{array}$ & 76.7 & $\mathrm{CH}$ & $\begin{array}{l}2.99 \text { (br ddd), } J=3.87,4.73, \\
10.76 \mathrm{~Hz}\end{array}$ \\
\hline 4. & 38.5 & $\mathrm{C}$ & - & 38.5 & $\mathrm{C}$ & - \\
\hline 5. & 49.6 & $\mathrm{CH}$ & $1.07(\mathrm{dd}), \mathrm{J}=1.22,11.14 \mathrm{~Hz}$ & 49.8 & $\mathrm{CH}$ & $0.91(\mathrm{~m})$ \\
\hline 6. & 18.5 & $\mathrm{CH}_{2}$ & $\begin{array}{l}1.40(\mathrm{~m}) \\
1.67(\mathrm{~m})\end{array}$ & 17.8 & $\mathrm{CH}_{2}$ & $\begin{array}{l}1.42(\mathrm{~m}) \\
1.62(\mathrm{~m})\end{array}$ \\
\hline 7. & 31.3 & $\mathrm{CH}_{2}$ & $\begin{array}{l}\beta: 2.30 \text { (ddd), } J=3.97,4.12,6.71 \\
\alpha: 2.46 \text { (ddd), } J=3.97,4.12,8.70\end{array}$ & 25.8 & $\mathrm{CH}_{2}$ & $\begin{array}{l}1.80(\mathrm{~m}) \\
2.01(\mathrm{~m})\end{array}$ \\
\hline 8. & 123.8 & $\mathrm{C}$ & - & 131.9 & $\mathrm{C}$ & - \\
\hline 9. & 141.0 & $\mathrm{C}$ & - & 135.2 & $\mathrm{C}$ & - \\
\hline 10. & 37.7 & $\mathrm{C}$ & - & 36.6 & $\mathrm{C}$ & - \\
\hline 11 & 20.9 & $\mathrm{CH}_{2}$ & $\begin{array}{l}2.00(\mathrm{~m}) \\
2.06(\mathrm{~m})\end{array}$ & 20.0 & $\mathrm{CH}_{2}$ & $\begin{array}{l}1.90(\mathrm{~m}) \\
1.98(\mathrm{~m})\end{array}$ \\
\hline 12 & 35.3 & $\mathrm{CH}_{2}$ & $\begin{array}{l}1.16(\mathrm{~m}) \\
1.67(\mathrm{~m}) \\
\end{array}$ & 28.5 & $\mathrm{CH}_{2}$ & $\begin{array}{l}1.35(\mathrm{~m}) \\
1.66(\mathrm{~m})\end{array}$ \\
\hline 13. & 46.7 & $\mathrm{C}$ & - & 44.1 & $\mathrm{C}$ & - \\
\hline 14. & 50.8 & $\mathrm{CH}$ & $1.84(\mathrm{dd}), J=6.87,8.70 \mathrm{~Hz}$ & 50.3 & $\mathrm{C}$ & - \\
\hline 15. & 43.1 & $\mathrm{CH}_{2}$ & $\begin{array}{l}\alpha: 1.82(\mathrm{dd}), J=2.44,8.70 \mathrm{~Hz} \\
\beta: 2.17(\mathrm{dd}), J=2.44,6.87 \mathrm{~Hz}\end{array}$ & 75.5 & $\mathrm{CH}$ & $4.92(\mathrm{dd}), J=5.42,9.47 \mathrm{~Hz}$ \\
\hline 16 & 126.7 & $\mathrm{C}$ & - & 34.7 & $\mathrm{CH}_{2}$ & $\begin{array}{l}\alpha: 1.69 \text { (dd) } J=3.23,9.47 \mathrm{~Hz} \\
\beta: 2.01 \text { (dd), } J=3.23,5.42 \mathrm{~Hz}\end{array}$ \\
\hline 17. & 140.3 & $\mathrm{C}$ & - & 45.2 & $\mathrm{CH}$ & $2.10(\mathrm{~m})$ \\
\hline 18. & 15.7 & $\mathrm{CH}_{3}$ & $0.75(\mathrm{~s})$ & 15.9 & $\mathrm{CH}_{3}$ & $0.76(\mathrm{~s})$ \\
\hline 19. & 20.2 & $\mathrm{CH}_{3}$ & $0.96(\mathrm{~s})$ & 18.9 & $\mathrm{CH}_{3}$ & $0.91(\mathrm{~s})$ \\
\hline 20. & 45.9 & $\mathrm{CH}$ & $2.27(\mathrm{t}), J=6.71 \mathrm{~Hz}$ & 47.2 & $\mathrm{CH}$ & $2.15(\mathrm{~m})$ \\
\hline 21. & 177.2 & $\mathrm{C}$ & - & 176.8 & $\mathrm{C}$ & - \\
\hline 22 & 30.4 & $\mathrm{CH}_{2}$ & $1.53(\mathrm{~m})$ & 30.6 & $\mathrm{CH}_{2}$ & $1.47(\mathrm{~m})$ \\
\hline 23. & 31.4 & $\mathrm{CH}_{2}$ & $1.93(\mathrm{t}), J=7.63 \mathrm{~Hz}$ & 31.4 & $\mathrm{CH}_{2}$ & $1.91(\mathrm{t}), J=7.42 \mathrm{~Hz}$ \\
\hline 24. & 154.8 & $\mathrm{C}$ & - & 154.8 & $\mathrm{C}$ & - \\
\hline 25. & 33.2 & $\mathrm{CH}$ & $2.28(\mathrm{sep}), J=6.59 \mathrm{~Hz}$ & 33.2 & $\mathrm{CH}$ & 2.17 (sep), $J=6.75 \mathrm{~Hz}$ \\
\hline 26. & 21.6 & $\mathrm{CH}_{3}$ & $0.96(\mathrm{~d}), J=6.59 \mathrm{~Hz}$ & 21.5 & $\mathrm{CH}_{3}$ & $0.93(\mathrm{~d}), J=6.75 \mathrm{~Hz}$ \\
\hline 27. & 21.6 & $\mathrm{CH}_{3}$ & $0.96,(\mathrm{~d}), J=6.59 \mathrm{~Hz}$ & 21.5 & $\mathrm{CH}_{3}$ & $0.93(\mathrm{~d}), J=6.75 \mathrm{~Hz}$ \\
\hline 28 & 106.8 & $\mathrm{CH}_{2}$ & $\begin{array}{l}4.72(\mathrm{~s}) \\
4.64(\mathrm{~s})\end{array}$ & 106.8 & $\mathrm{CH}_{2}$ & $\begin{array}{l}4.72(\mathrm{~s}) \\
4.63(\mathrm{~s})\end{array}$ \\
\hline 29. & 28.2 & $\mathrm{CH}_{3}$ & $0.92(\mathrm{~s})$ & 28.1 & $\mathrm{CH}_{3}$ & $0.89(\mathrm{~s})$ \\
\hline 30 & 15.9 & $\mathrm{CH}_{3}$ & $0.70(\mathrm{~s})$ & 15.8 & $\mathrm{CH}_{3}$ & $0.69(\mathrm{~s})$ \\
\hline 31. & 17.1 & $\mathrm{CH}_{3}$ & $1.81(\mathrm{~s})$ & 18.1 & $\mathrm{CH}_{3}$ & $0.93(\mathrm{~s})$ \\
\hline 32. & & & & 167.0 & $\mathrm{C}$ & - \\
\hline 33. & & & & 42.4 & $\mathrm{CH}_{2}$ & $3.28(\mathrm{~s})$ \\
\hline 34. & & & & 167.9 & $\mathrm{C}$ & - \\
\hline & & $\mathrm{OH}$ & $4.34(\mathrm{bd}), \mathrm{J}=4.73 \mathrm{~Hz}$ & & $\mathrm{OH}$ & $4.31(\mathrm{bd}), J=3.87 \mathrm{~Hz}$ \\
\hline
\end{tabular}


Table 2: Cytotoxic activities of compounds 1-5 and 7.

\begin{tabular}{lccccccc}
\hline $\begin{array}{l}\text { Cell } \\
\text { lines }\end{array}$ & & & \multicolumn{6}{c}{ Cytotoxicity $\mathrm{IC}_{50}(\mu \mathrm{g} / \mathrm{mL})$} \\
& $\mathbf{1}$ & $\mathbf{2}$ & $\mathbf{3}$ & $\mathbf{4}$ & $\mathbf{5}$ & $\mathbf{7}$ & Epothilon B (standard) \\
\hline L929 & 13 & 49 & 9.8 & 8.2 & - & - & 0.0014 \\
KB3.1 & 6.8 & 67 & 17 & 6.2 & 5.1 & - & 0.00022 \\
A431 & 14 & 50 & 21 & 6.6 & $\mathrm{nt}$ & $\mathrm{nt}$ & 0.0006 \\
MCF-7 & 7.2 & 46 & 25 & 5.1 & $\mathrm{nt}$ & $\mathrm{nt}$ & 0.0004 \\
PC-3 & 6.8 & 46 & 24 & 4.5 & $\mathrm{nt}$ & $\mathrm{nt}$ & 0.0002 \\
A549 & 4.5 & 62 & 27 & 3.5 & $\mathrm{nt}$ & $\mathrm{nt}$ & 0.005 \\
\hline
\end{tabular}

a (-)- not active at concentration $\leq 37 \mu \mathrm{g} / \mathrm{ml}$

bnt-not tested
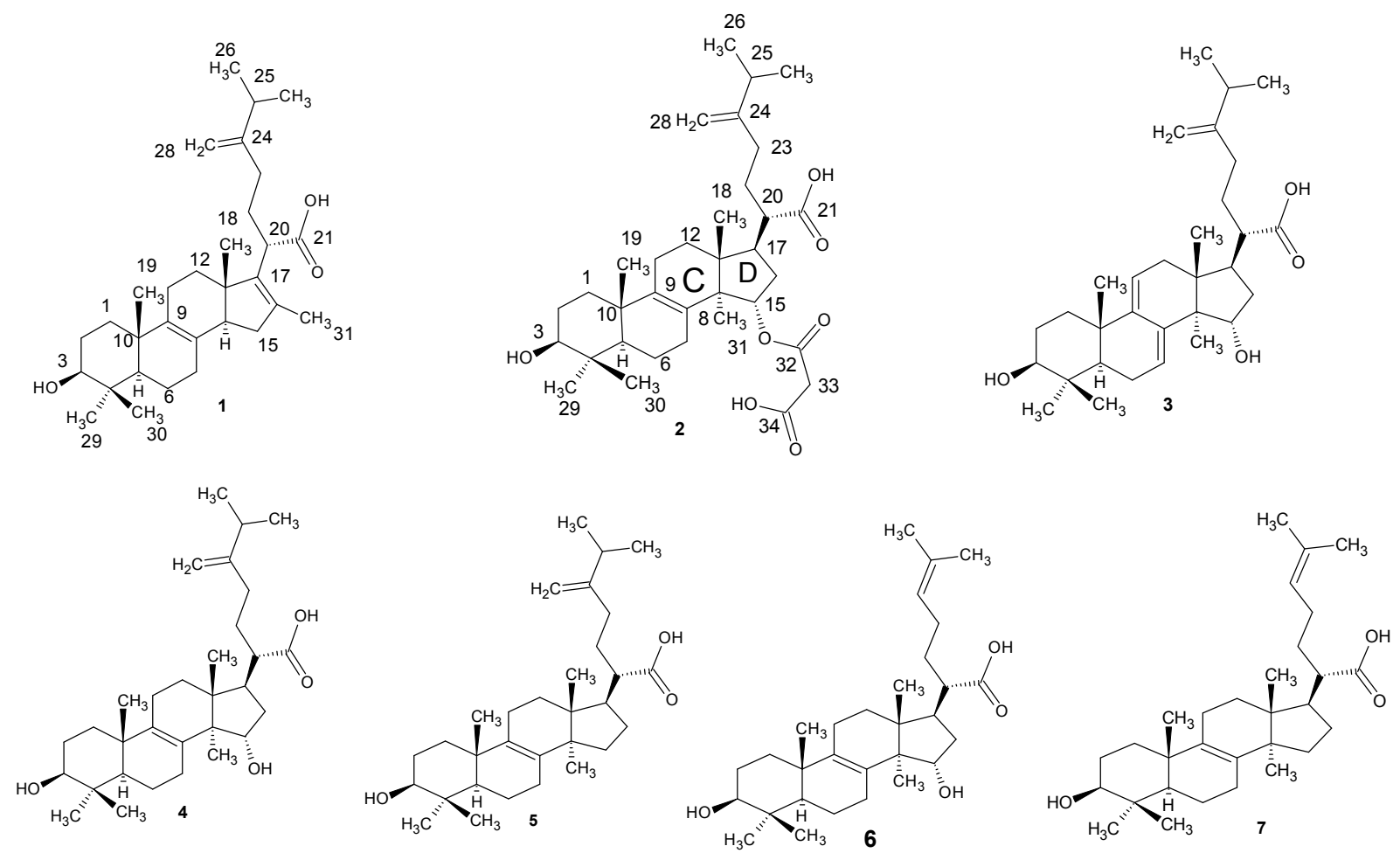

Figure 1: Chemical structure of compounds 1-7 

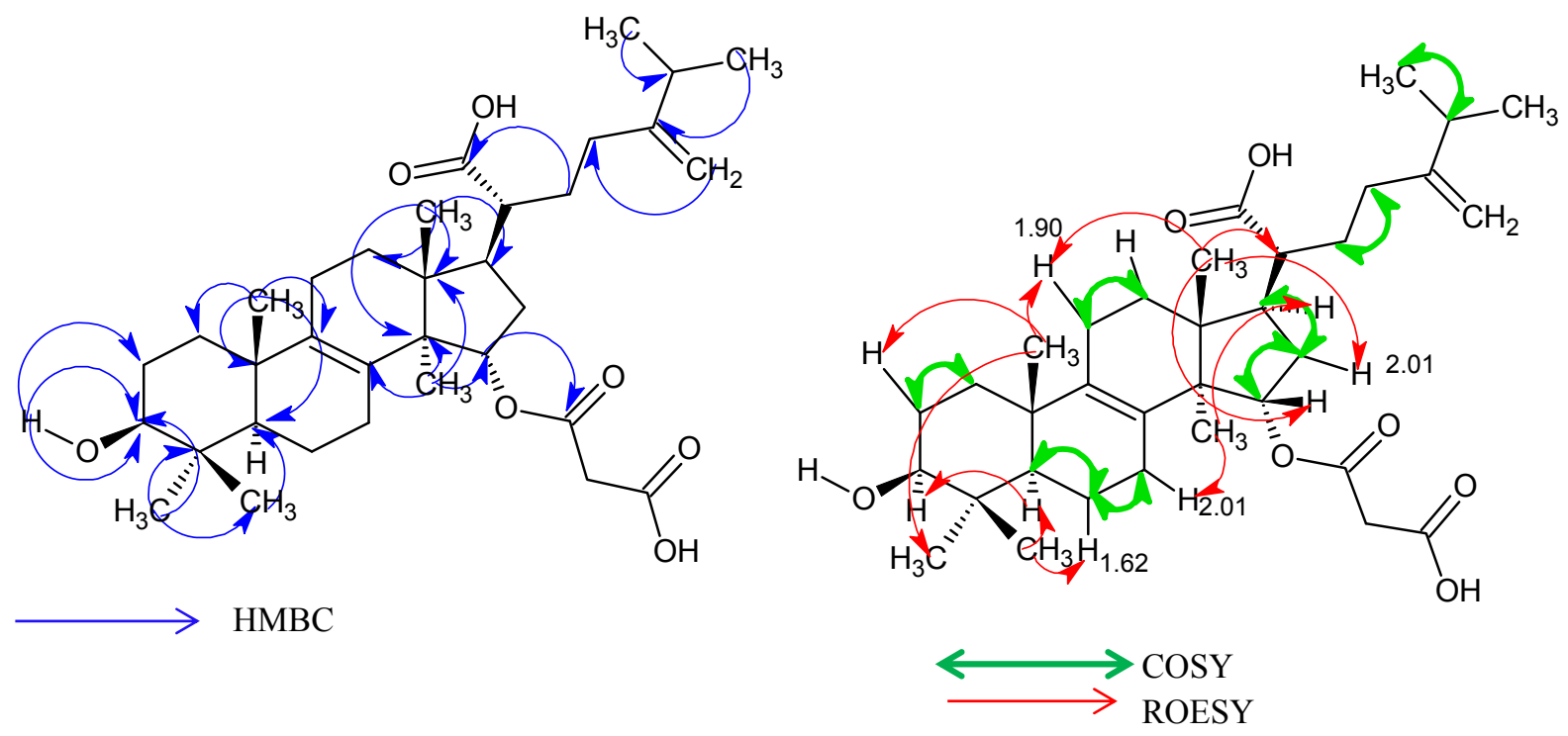

Figure 2: HMBC, COSY and ROESY correlations of 2 